\title{
Towards a Human Capabilities Conscious Enterprise Architecture
}

\author{
Ermias Abebe Kassa ${ }^{1,2, *(D)}$ and Jan C. Mentz ${ }^{1}$ (D) \\ 1 Department of Information Systems, School of Computing, University of South Africa, \\ Johannesburg 2092, South Africa; mentzjc@unisa.ac.za \\ 2 School of Information Science, College of Natural \& Computational Sciences, Addis Ababa University, \\ P.O. Box 80899, Addis Ababa 3614, Ethiopia \\ * Correspondence: ermias.abebe@aau.edu.et
}

Citation: Kassa, E.A.; Mentz, J.C.

Towards a Human Capabilities Conscious Enterprise Architecture. Information 2021, 12, 327. https:/ / doi.org/10.3390/info12080327

Academic Editors: Kostas Vergidis and Costas Vassilakis

Received: 23 March 2021

Accepted: 23 June 2021

Published: 13 August 2021

Publisher's Note: MDPI stays neutral with regard to jurisdictional claims in published maps and institutional affiliations.

Copyright: (C) 2021 by the authors Licensee MDPI, Basel, Switzerland. This article is an open access article distributed under the terms and conditions of the Creative Commons Attribution (CC BY) license (https:// creativecommons.org/licenses/by/ $4.0 /$ )

\begin{abstract}
This conceptual paper argues that enterprise architecture (EA) should move towards a conscious human-centered conception of the enterprise. Employing the conceptual methodological approach of theory synthesis and drawing on the extant literature in enterprise architecture as well as pertinent social and organizational theories, we suggested foundational propositions that could holistically serve as a theoretical lens for (re)viewing the foundations of EA within a progressive conscious enterprise agenda. The novel contribution of the paper is the introduction of human capabilities approach (HCA) as a method theory, to supplement systems and stakeholder theories, for design and evaluation of enterprise architecture in the modern enterprise. The paper concludes by showing the implications of the propositions for practitioners and researchers.
\end{abstract}

Keywords: enterprise architecture; human capability approach; socio-technical architecture; stakeholder theory; sustainability

\section{Introduction}

Enterprise Architecture (EA) is the blueprint that drives business and information technology (IT) decisions in an organization or organizations that share the same or similar vision and mission [1-3]. According to Lapalme et al. [4], EA is an integrative concept that binds the socio-technical organization, built from interacting components, with its ever-changing environment using accepted enterprise design and governance principles. Alternatively, EA can be understood as an abstraction of the interactions among the enterprise, its environment, and technology in current as well as in possible future states [1].

The history of EA began perhaps in the 1960s with IBM's Business Systems Planning (BSP) methodology, although it was not until the second half of the 1980s that the first framework was published [5]. Since then, EA has been developing in several distinct yet interrelated fields including industrial engineering, organizational theory, computing, and information systems.

In their widely cited work, Lapalme et al. [6] captured the progression of EA in three stages; i.e., the technical, the socio-technical, and the ecosystem schools [6,7]. The three schools represent the historical evolution of EA in which the technical is subsumed under the socio-technical, which in turn is appropriated and expanded by the ecosystemic. Initially, EA was driven by technical approaches inspired by engineering and architecture methods [8]. The focus was on IT architecture and the view was relatively mechanistic and reductionist [7]. In the socio-technical systems view, the aspiration was to create positive synergy between the technical and social constituents of the system and yield joint optimization of the needs of individuals and the organization [9]. The ecological adaptation school extends the previous two views to embrace the ecosystemic concerns of society to achieve innovation and sustainability [6]. The focus is therefore shifting towards value systems [7]. 
As the ecological adaptation view takes root, EA research interests are orientating towards the integration, standardization, and elaboration of EA's non-technical and theoretical foundations [10-12]. The need for a holistic treatment of EA to account for changing economic, environmental, and human conditions is also emphasized by several researchers $[4,11,13]$. However, we feel that the EA literature has not yet given human values and human capabilities the place they deserve in EA design. Secondly, despite the many theories employed in EA, we understood that EA's theory and practice are less informed by human capabilities consciousness and, to some extent, stakeholder theory, which could better align with the EA of the future [14-16].

We aim to address these gaps by positing human capabilities conscious EA as a logical extension to the enterprise ecological adaptation school [4]. In this paper, we introduce the human capabilities approach (HCA) as an integrative framework to promote a humancentric EA approach. In the tradition of conceptual studies [17], we hope to envision, explicate, relate, and advocate for human capabilities conscious EA [18,19].

The aim of this work is thus twofold. The first is to sensitize practitioners to the need for and potentials of embedding human capability conception in the design and evaluation of EAs. The second aim is to present the EA research community with potential areas of further investigation in creating theories and tools for instilling human capability consciousness in EA design. In reaching these aims we hope to encourage the communities of research and practice to design and adopt formal mechanisms that would allow EA to function in an environment where the demand for equity, justice, sustainability, and relative progressive ideals is high $[4,13]$.

We designed our investigation based on the prescriptions of Jaakkola [20] and Mora et al. [21]. As a conceptual study, our attempt was to systematically assemble, organize, and interpret theories and concepts pertinent to human capabilities consciousness in EA to create new avenues of application in research and practice [21-23]. Rigor in the conceptual paper is achieved through identifying the knowledge gap; justifying the selection of theories; explicating the role of the theories; and arguing via claims, grounds, and warrants [20,21]. Hence, in Section 2, we framed the appreciation, or the lack thereof, of the higher purpose of the enterprise and what it entails to EA as a knowledge gap. In Section 3, we explicate and justify the selection of the theories considered for the study followed by the description of the roles each play. Section 4 presents the propositions which are the culmination of the chain of logical reasoning beginning with the justification for the existence of the enterprise. The propositions are the pillars that support the human conscious EA. The fundamental implications of the propositions are forwarded in Section 5. The paper concludes with a discussion of the potential areas identified for further inquiry. Figure 1 captures the conceptual flow of the paper.

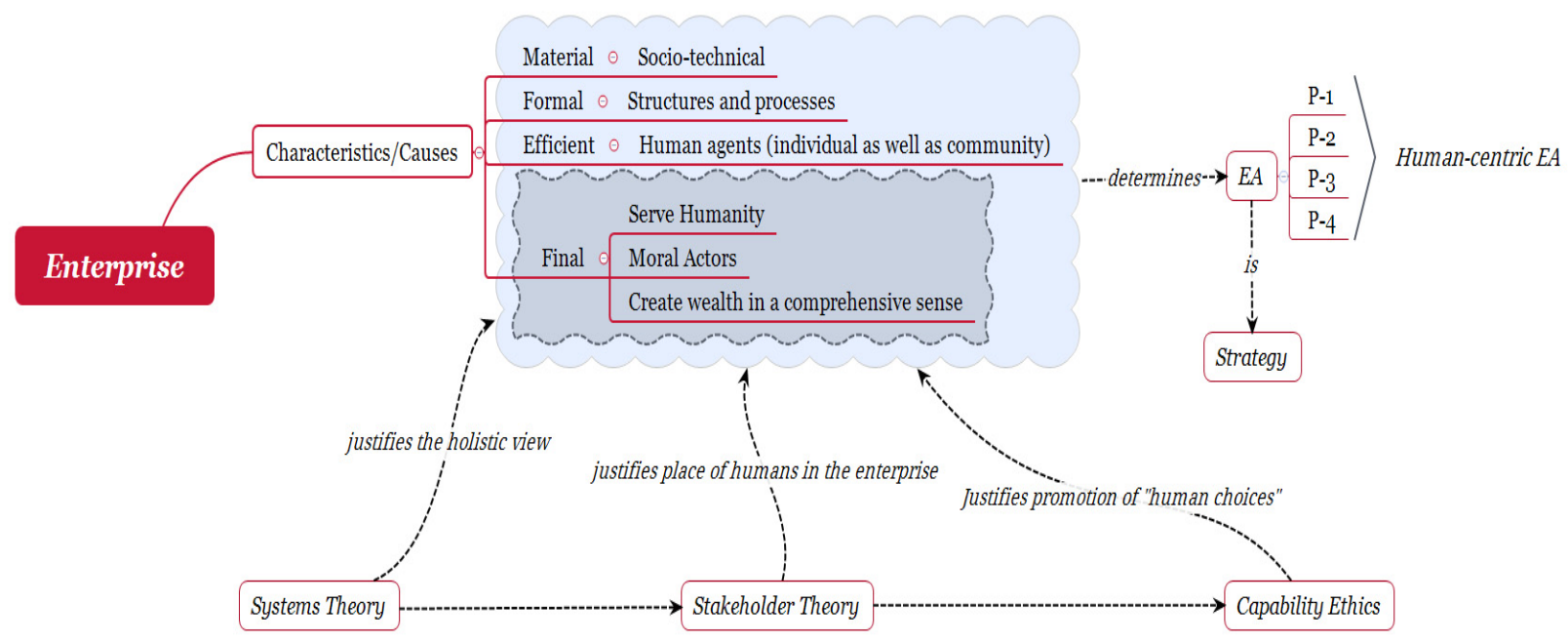

Figure 1. Conceptual flow of the paper. 


\section{The Higher Purpose of Enterprise Architecture}

Humans have long recognized the importance of organized work to achieve higher levels of efficiency and effectiveness. However, as human societies progressed, the pure profit motive started to take center stage in most organizational endeavors whereby humans (employees, customers, etc.) became instrumentalized to the extent that they are considered extensions of technical tools to achieve an economic benefit for the enterprise [24,25]. There are cases where enterprises instrumentalize, dehumanize, and alienate their stakeholders, except perhaps for the stockholders [26]. Instrumentality, an aspect of the notion known as objectification, occurs when the objectifier uses the objectified human or animal as a tool for the satisfaction of the objectifier's goals [27]. Dehumanization, on the other hand, is the process by which a human is stripped of his innate individualness by the actions or behavioural manifestations of other humans, institutions, or even by self [27]. Alienation is the notion that a human engaged in an exploitative economic relation is estranged from work, the fruits of his labour and ultimately from his species-essence [27].

The pure profit motive and unscrupulous manipulation of society by enterprises are not however without consequence. Social thinkers from Aristotle to Marx and Sen forewarned us of the imminent social discord due to cynically exploitative economic relations $[18,28]$. Consequently, there have been pressures to transform organizations through redirection of their focus from shareholder profitability to societal prosperity. This is an invitation to reevaluate and redefine the purpose of organizations.

In Aristotle's metaphysics, any physical (for example, a building), spiritual (for example, music), or social (for example, the enterprise) construction would have a material, formal, efficient, and final cause [29-31]. This final cause (telos), which justifies the existence of the construction, is also its ultimate purpose. The telos is especially apparent in human-made systems, organizations for example, since humans apply consciousness, intentionality, intelligence, and deliberation in designing such systems.

Enterprises are higher-order complex systems constructed from socio-technical components that are purposefully designed by humans to realize a goal or mission [32-35] (In this paper, the word enterprise assumes two related yet slightly different meanings. In the first generic sense, an enterprise is an organization created by humans to attain their efficiency and effectiveness goals [32]. In this paper, the word organization can sometimes appear in lieu of enterprise within this broader context. The second flavour is a referent to the specialized sense the word is used in EA. In this sense, the enterprise can be an organization, a set of organizations, or even an organizational unit tied together to serve a strategic purpose [32]. In this context, we used only enterprise as in enterprise architecture.). Any typical definition of an enterprise recognizes these fundamental constituents of the system, namely socio-technical elements (material cause), an entrepreneurial agent (efficient cause), interconnections (formal cause), and a reason for existence (final cause) [36]. Given this recognition, the question arises as to what the overarching purpose of enterprises, and by extension, EA, is. To answer to this question, we must look at developments in several societal endeavors.

First, organizations are moving away from exclusively technical-, material-, and owner-centered thinking towards a holistic, human-value driven, and stakeholder-centered thinking and decision making. There is a growing understanding that enterprises, in principle, can and should be ethical, producing a win for all stakeholders (investors, employees, customers, suppliers, environment, and society) [26]. As a result, stakeholders are taking center stage in many organizational decisions.

Secondly, we are witnessing marked progress in human consciousness [37]. Inequalities are being challenged everywhere [37]. Individuals as well as society are becoming more conscious about the impact of their actions towards other humans/societies, other species, the physical environment, and future generations.

Thirdly, digital technologies are making us more connected, but at the same time more predictable, controllable, and homogeneous [38,39]. Preserving individual and societal heterogeneities is something desirable unless the goal is to create a regimented, tech 
dystopia full of robot-like humans. Ethics is therefore becoming intrinsic to technological designs with the objective of maintaining and expanding human capabilities [38,39].

Bringing these strands of social development together, Enderle [40] asserts that organizations: (a) can plan and operate within the limits of environmental constraints, (b) are moral actors, and (c) have the purpose of creating wealth in a comprehensive sense, i.e., physical, human, natural, and social wealth or capital. The Stiglitz-Sen-Fitoussi commission report [41] concurs with the latter assertion. Solomon [42] (1024), within the narrower context of business, describes the organization as "a human institution in service to humans and not as a marvelous machine or in terms of the mysterious 'magic' of the market". The higher purpose of enterprises, therefore, should be to serve humanity and Enderle's principles can serve as a progressive platform to promote diversity, humanism, and ethics in designing our enterprises $[26,43]$.

$\mathrm{EA}$, as a strategic tool that translates the enterprise values and strategy to information system services, naturally inherits the purposes of the enterprise [3,44]. Enterprises should, out of necessity, put in place an EA that not only accounts for economic, social, and ecological consideration but also human choices. EA will also have to adapt to the social, psychological, and technological changes in society to stay relevant [2]. For instance, Gartner's emergent architecture principles [16,45] suggests that the future is for goal-oriented and rule-bound actors. Goal-orientation means that employees may want to promote their own interests without necessarily prevailing over organizational objectives [46]. Rulebound, on the other hand, implies that EAs need to avoid detailed specifications and allow for choice within the bounds of a minimal rule set. Active ecological adaptation [6] is therefore sought in EA to allow people to pursue well-being, human growth, and social development $[43,47]$. There is a need for change in the conceptualization of enterprise design towards the humanization of enterprises and the affordance of meaningful work bringing human capabilities center stage in EA planning and evaluation. We call the new EA, which will be built on these tenets, the conscious enterprise architecture (adopted from [26]). This could also be considered as a logical extension to the enterprise ecological adaptation school of EA thought [6].

The consciousness we are referring to is a consequence of the understanding that decision making at all levels is value laden. It calls for foregrounding moral values of human dignity and justice in designing products and processes. In Section 3, we draw on systems theory, stakeholder theory, and the HCA to forward certain propositions in support of a conscious EA. In passing, we note that while moral agency ranges from the micro (individual) level to the meso (organizational) and macro (system) levels, the hierarchic nature of systems allows us to safely assume that what applies to the lower-level agents also applies to higher level agents. Thus, when we talk about organizations, we are also referring to economic (national) systems.

\section{Contributing Theories}

\subsection{Theory Sampling}

Organizations use EA to align their business and technology strategies [12,13]. In this role, EA's efficacy is contingent on the organizational foundations, which form a tight linkage between the business and its technology. The concepts that describe these foundations can be found in related fields of study such as organizational theory, technology, ethics, and economics. By drawing on these fields, EA knowledge is evolving towards an increased understanding of stakeholder engagement, organizational sustainability, and ecological adaptation.

Researchers have suggested tens, if not hundreds, of theories for use in EA. For example, Kotusev et. al. [14] compiled a list of 32 theories proposed or actually applied in EA. They also provided a database of 123 theories which have potential for use in EA. Obviously, there may be theories in diverse domains as economics, management, philosophy, sociology, etc., whose potential is yet to be acknowledged in EA. Within 
practical limits of time and space, we selected two theories from EA and another from economics to argue for human capabilities conscious EA.

The selection of the theories followed the procedure suggested by [15]. In the method of [15], we include a theory $t$ to the set of theories S2 from a potential list (kernel theories) $\mathbf{K}$, if $\boldsymbol{t}$ satisfies the $\mathbf{S 1}$ of properties. As indicated in Section 1, our intention is to propose an integrative framework that could extend the ecosystem school of EA thought. As such, our S1 is made of characteristics a theory, method, or tool must satisfy to support the ecosystemic view $[6,7]$.

We made a purpose sampling of the theories by reading the description of the kernel theories provided in Kotusev et. al. [14]. We considered systems and stakeholder theories as domain theories as they already have some application in the EA literature [14,15]. We deployed the HCA as a method theory to serve as an integrative framework. The HCA provides supplementary value by informing the other two theories [20]. See Table 1 for tentative evaluation of the theories based on some essential characteristics of ecosystemic EA. The sources cited are only exemplars.

Table 1. Potential of selected theories to accommodate and expand ecosystemic EA.

\begin{tabular}{|c|c|c|c|}
\hline \multirow{2}{*}{ Characteristics of Ecosystemic EA (S1) } & \multicolumn{3}{|c|}{ Theories (S2) } \\
\hline & System Theory & Stakeholder Theory & HCA \\
\hline Holism [6] & $+[15,35,48]$ & $?$ & $+[49,50]$ \\
\hline Business ecosystem (diversity of inhabitants) $[6,51]$ & $+[35,52]$ & $+[53,54]$ & $+[55,56]$ \\
\hline $\begin{array}{c}\text { Fosters organizational innovation, sustainability, } \\
\text { and organizational coherence }[6,51]\end{array}$ & $+[52]$ & $+[57]$ & $+[58]$ \\
\hline System-in-environment coevolution $[6,51]$ & $+[35,52]$ & $+[59]$ & $+[58]$ \\
\hline Emergent Behavior [51] & $+[35,52]$ & - & ? \\
\hline Self-organization [51] & $+[35,52,60]$ & - & $+[61]$ \\
\hline Decentralized governance [51] & $+[60]$ & - & $+[62]$ \\
\hline Collaboration, competition and co-opetition [51] & $+[60]$ & $+[63]$ & $+[63]$ \\
\hline Environment can be changed [6] & $+[52,64,65]$ & $?$ & $+[58]$ \\
\hline Joint design of all organizational dimensions [6] & $+[52]$ & $+[63,66]$ & $+[58]$ \\
\hline Dialogue fostering [6] & $+[67,68]$ & $+[63,66]$ & $+[69]$ \\
\hline Larger group facilitation [6] & $+[67]$ & $+[63]$ & $+[70,71]$ \\
\hline Fostering sense-making [6] & $+[52,72]$ & $+[53,54]$ & $+[56,58]$ \\
\hline Value sensitive design $[73,74]$ & $?$ & $?[53,54]$ & $+[58]$ \\
\hline
\end{tabular}

Key: (+) Conforms; (-) Does not conform; (?) Incomplete.

\subsection{Systems Theory}

Systems theory is an overarching analytical framework for diagnosing universal problems [35,36]. It does not seek to explain; rather, it seeks to magnify and expose the interactions among system components and their environment, which yield a certain outcome [52]. In the context of organizational management, systems theory challenges the mechanistic world view propagated by bureaucratic management and identifies organizations as organic entities composed of interacting components existing in a hierarchic structure within an environment $[64,75,76]$. Hence, instead of using reductionism and linear causality, systems thinking relies on holism and causal loops to expose the intricate causality relations that exist within organizations [77].

A system is defined as a set of interacting components, organized in a certain fashion to achieve a certain goal. The system is defined by its components and their interaction, its boundary, and its behavioral output (purpose) [36]. The purpose of the system is what essentially determines the system's behavior [36]. 
Giachetti [33] (4) describes an organization as "a complex, socio-technical system that comprises interdependent resources of people, information, and technology that must interact with each other and their environment in support of a common mission." As it appears, Giachetti's definition is anchored on systems theory in so far as it addresses the three fundamental constituents of a system, i.e., elements, interconnections, and a reason for existence [36]. On Boulding's eleven-scale hierarchy of systems, organizations are placed at the complexity levels of $9-10$, identified as societal systems [32,34,35].

Organizations are open, organic, dynamic, allopoietic, goal-directed, and meaningdriven systems, the behavior of which is tempered by the environment $[35,78]$. Complex human systems exist for a purpose, and the purpose creates a context that in turn gives meaning to all the activity that takes place in that context. Campbell, Coldicott, and Kinsella [78] conclude that in the context of bigger social systems such as organizations, the overall purpose of unleashing systemic thinking is to understand the context under which people operate and how that context modifies behavior.

\subsection{Stakeholder Theory}

The predominant thinking in business has been that the interests of the owners should always get primacy over all other interests. Agency theory for instance, considers management as the agent of the shareholders on whose behalf financial investments should multiply [79]. The agents (management and other employees) are expected to channel their efforts to achieve organizational goals instead of their own personal objectives [80-83]. In this view, economic value is the single most important bottom line that matters. Hoogervorst [25], while asserting that coherence and consistency should be essential characteristics of an enterprise in the interest of human stakeholders, contends that enterprises are promoting the interests of shareholders at the expense of other stakeholders (particularly of employees).

Standing in direct opposition to theories that exclusively promote shareholder value, stakeholder theory attempts to expand the bottom line of the enterprise by incorporating the interests of several stakeholders in business decision making. Stakeholder theory holds that a host of stakes should be considered when determining the purpose of the enterprise. The emphasis on the value of all stakeholders in corporate decision making is not only ethical but also strategically sought $[79,80]$.

Stakeholder theory is unapologetically moralist. It invokes a wide variety of moral theories such as common good principles, feminist ethics, Kantianism, and a doctrine of fair contracts to justify its essence and aspirations [84]. Stakeholder theory is consequently prescriptive in its approach [79].

A stakeholder is defined as someone with interest in the development, operations, outputs, and ecological outcomes of a system [85]. The stakeholder could be a person, a group of persons, or a societal system such as an organization. Six groups of stakeholders are recognized in the literature, namely, employees, customers, investors, suppliers, society, and the environment $[79,86]$. Some of these stakeholders are individual human beings while others can be groups of individuals, organizations, or even non-humans.

According to stakeholder theory, organizations are expected to create value for their stakeholders not only to ensure the latter's continued engagement but also in the overall interest of shareholders [53]. That is, organizations should not attempt to separate shareholder value from the values of other stakeholders [53]. For example, the employee expects to gain wellbeing, security, and equity; the customer looks for product or service quality, safety, and transparency; and the investor expects to get an economically sensible return on investment $[79,86]$ without jeopardizing the interests of others.

Despite its insistence on the need to embrace and advance the needs of all stakeholders, stakeholder theory understands that some stakeholders are more important than others by virtue of their merit $[79,84]$. An overly loose interpretation of stakeholders in any enterprise may lead to financial ruin, shareholder disenchantment and desertion [87]. Therefore, we 
use the term stakeholders to describe people that have a major and legitimate stake on the organization $[79,80,88]$.

\subsection{The Human Capabilities Approach (HCA)}

The HCA was first proposed by the Nobel laureate Amartya Sen in a series of works that he and his collaborators published starting from the 1980s [89,90]. Several people have contributed to the expansion of the conception and application of the HCA in so many domains [89].

First and foremost, the HCA is a paradigm in economic thinking that is posited against classical welfare economics [91,92]. The HCA is a broad normative framework for the evaluation and assessment of individual well-being and social arrangements, the design of policies, and proposals about social change [93].

The core claim of the HCA is that assessments of well-being or quality of life of a person, and judgements about equality or justice, or the level of development of a community or country should not primarily focus on resources, or on people's mental states, but on the effective opportunities that people must lead the lives they have reason to value $[91,93]$. Unlike resource based economic theories, the HCA focuses on the ends of well-being rather than the means. Having this or that resource may not matter at the end if those resources do not expand the capability space of the owner. The means are, therefore, instruments to bring humans to their higher order goals of increased well-being, justice, and development [93]. Thus, the HCA targets the promotion of human capabilities by which we mean the opportunity space available to humans to operate in $[40,93]$.

The HCA takes an ethical-individualism stance arguing that we should only consider individuals as the decisive units of moral concern [94]. That does not, however, disqualify groups from coming into play when analyzing policy decisions or evaluating artefacts and structures.

According to the HCA, the ends of well-being, justice, and development should be conceptualized in terms of people's capabilities to function; that is, their effective opportunities to undertake the actions and activities that they want to engage in and whom they want to be. These beings and doings, which Sen calls functionings, together constitute the value of life [95]. Functionings include working, resting, being literate, being healthy, being part of a community, being respected, and so forth. The distinction between achieved functionings and capabilities is between what is realized and what is effectively possible; in other words, between achievements on the one hand, and freedoms or valuable options from which one can choose on the other $[89,93]$. What is ultimately important is that people have the freedoms or valuable opportunities (capabilities) to lead the kind of lives they want to lead, to do what they want to do, and be the person they want to be. Once they effectively have these substantive opportunities, they can choose those options that they value most. For example, every person should have access to health services provided by the government. However, the HCA recognizes that a person may refuse to use e-health services available to the public for some personal or religious reason. The HCA is therefore focused on choice or freedom, holding that the crucial good societies should be promoting for their people is a set of opportunities, or substantial freedoms, which people then may or may not exercise in action: the choice is theirs. It commits to respect for people's power of self-definition.

When one talks of human capabilities it is of course within constraints. An agent operates within certain constraints when he/she tries to expand his/her functionings. These constraining factors make up the basis for sustainable decision making as the agent should recognize the impact of their decisions on current and future ecosystems [96,97]. Whether the functioning constraints are automatically loaded at time of decision making or are externally imposed is, however, a contested terrain [96,97].

Amartya Sen refused to provide a special list of capabilities, arguing that such a list would limit the applicability of his theory [95]. Instead, he suggested that organizations should develop their own list through continued dialogue with their stakeholders, which is consistent with the approach followed in Stakeholder Theory $[40,95]$. While 
Sen's proposition is acceptable on one level, it rendered the theory impractical for several purposes [50,93]. Martha Nussbaum critiqued Sen's refusal to provide a list of common or critical capabilities, and went on to develop a core list of functionings. Nussbaum's central capabilities are: (1) life; (2) bodily health; (3) bodily integrity; (4) senses, imagination, and thought; (5) emotions; (6) practical reason; (7) affiliation; (8); Other species; (9) play; and (10) control over one's environment $[19,98]$.

Martha Nussbaum was the first to show the intimate link between Sen's capability approach and Aristotelian ethics $[19,91]$. Nussbaum argued that the ultimate goal of achieved capabilities is what Aristotle called human flourishing [19]. Furthermore, she expounded on Sen's sketches and made its application in wider realms possible, which was immensely acknowledged by Sen himself [91]. Nussbaum's approach is now widely referred to as capability ethics to make a nuanced distinction from the capability approach of Sen [91]. Here, in this paper, we will continue to use HCA as consolidative term superseding both.

Gaining wider credence, the HCA has been in use in diverse domains including developmental and welfare economics, political philosophy, as well as in information and communication technologies for development (ICT4D) and other technology related domains $[49,93]$. In ICT4D, several research outputs have been produced that deployed the HCA as an evaluative framework for gauging the merits of artefacts in expanding human choices [99-102]. In the same vein, the HCA has obtained applications in the wider technology design arena $[49,50,103]$. Studies using the HCA as an ethical theory that guides corporate behavior are under investigation $[40,104]$.

\section{The Human Capabilities Conscious Enterprise Architecture}

In Section 2, we argued that the higher purpose of the enterprise is to serve the overall flourishing of humanity. EA, as a systematic organizational view and a mechanism of organizational strategic making, should align to this purpose of the enterprise. Systems theory, stakeholder theory, and the HCA are used as foundations to build the proposed human capabilities conscious EA. In the following, we present four foundational propositions which lead us to the conscious EA. The propositions are a synthesis of the interactions between the EA literature and the theories covered in Section 3.

\subsection{Enterprise Architecture as Socio-Technical Architecture}

EA can be understood as a purely technical discipline aimed at modelling a system architecture to serve the interests of the enterprise. In such a conception of EA design, the technical component has been stressed much more than the social [59].

However, several researchers emphasized the need for a holistic treatment of EA $[4,11,13]$. Particularly, Lapalme et. al. [4], in a more extended treatment of EA prospects, stressed that a holistic analysis of EA which takes account of the changing economic, environmental, and human conditions is required.

Indeed, there are compelling reasons to support the holistic treatment of EA. To start with, the core of EA lies in the term enterprise, which is nothing but a socio-technical system [59]. Several management theories demonstrated that organizations and their governance cannot be explained through the exclusive use of engineering-oriented theories, techniques, and tools [105]. Secondly, technology is implemented in a social context [106]. Even when the technology is autonomously functioning, such as in self-driven vehicles, its use and the impacts thereof cannot escape social scrutiny. Thus, it might be instructive to understand EA as lying at the intersection of the enterprise, technology, and the enterprise ecosystem and therefore, the socio-technical approach seems appropriate in the study of EA. The holistic treatment of EA is possible when we conceptualize EA as a sociotechnical architecture.

The theoretical basis for understanding EA as socio-technical architecture, and for our purpose, human-centric architecture is to be found in theories of management and architecture. More relevant to EAs are organizational theories which elevate the place of the human 
element in the organization. Systems theory (see Section 3.2), for instance, captures the human as well as the technical components of the system with all the intricate relationships within and outside the bounds of the organization $[107,108]$. This holistic view forms the theoretical backdrop even for such ideals as stakeholder and sustainability theories.

Systems theory informs us that enterprises are socio-technical systems to the extent that (a) they are composed of human as well as technical components, and (b) they have values to uphold [34]. Furthermore, Daft [43] outlines four important characteristics of the enterprise, which are: (a) being a social entity despite the extended use of technology, (b) goal-directedness, (c) intentionality of design, and (d) having environmental interrelation.

Socio-technical situatedness is natural to EA. EA inherits all socio-technical design principles $[68,109]$. See Table 2 for sample quotations from the EA literature.

Table 2. EA as socio-technical architecture.

Socio-Technical System Meta-Principles for Design

Design is systemic, emergent, and context-sensitive

Values, organizational culture, and mindsets are central to design

Design involves making choices and trade-offs

Design should be business and user-centered

\section{Characterization of EA}

"[t]he fundamental organization of a system embodied in its components, their relationships to each other, and to the environment" [110]

“... enterprise architecture is a system of systems" [48]

“... the principles guiding its design and evolution" [110]

“. . . all relations describing EAP [(enterprise architecture planning)] mechanisms and their effects are significantly moderated by organizational culture" [111]

"Normative principles limit design freedom. They are, however, not the only statements which limit design freedom. Requirements also limit design freedom." [112]

The why and the who of the Zachman framework define the stakeholder and the business purpose as key components of EA. $[113,114]$

Design is an extended social, contingent process which is socially shaped
"... the lack of focus on the 'people' aspects of EA could be the reason why many organisations still struggle with EA implementation." [115]

Thus, an exclusively technical and structural understanding of organizations is impractical. An enterprise is a social entity consciously constructed by humans to achieve human goals [32,82]. The social and technical elements that make up the enterprise are in continuous interaction in the performance of the enterprise's essential functions to achieve stakeholder goals [43]. EA, as an extension to enterprise strategy, should therefore be considered as a socio-technical architecture designed to cater for the needs of stakeholders $[47,59]$. Hence, our first proposition is:

\section{Proposition-1. Enterprise architecture is socio-technical architecture.}

\subsection{EA as an Instrument for Advancing Stakeholder Value}

For a long time, the way stakeholders were conceptualized and treated in EA has been in a narrow, system user sense [116]. Only those stakeholders who interact with the EA by either providing inputs or those who must comply with the EA specifications were taken as stakeholders $[116,117]$. This narrow definition of the stakeholder in EA perceives the stakeholders as objects of interest which could be employed to achieve the goals of the enterprise. On the other hand, there is some level of recognition of stakeholders' needs, goals, and expectations in EA. For instance, the ISO/IEC/IEEE 42010:2011 standard acknowledges stakeholders with their concerns and views [118,119].

Several researchers have identified heterogeneity of stakeholder interests as one of the most prominent challenges in EA [2,3]. This variety in stakeholder values is not to be shunned, though. Rather, it is to be captured, magnified, and converted to beneficial 
organizational capabilities. The strategic role of EA is to serve as an instrument for creating common understanding and reference among the stakeholders of the enterprise who often times have conflicting interests and views [120]. In this strategic view, we assert that the stakeholder is an actor with his/her own choices and interests, and the relationship should be one of mutuality. Thus, EA should expand the choices of stakeholders. In this way, we can tightly tie the interests of the shareholders, the other stakeholders, and the organization in general. Articulating the needs, goals, and expectations of the various stakeholders and striking a balance among the competing interests of stakeholders would therefore be the task of the enterprise architect $[118,120]$. This is what we call the conscious EA.

Haines, Aller-Stead, and McKinlay [108] indicated that a system may seek to achieve multiple outcomes as it is composed of system components with different goals. The implication of Proposition-1 is recognizing all stakeholders as goal-directed, and channeling EA design towards advancing the values of the stakeholders. As allopoietic societal systems, organizations depend on external as well as internal entities, who define their purpose [35]. As a result, the purpose of the organization can only be fully investigated through stakeholder analysis and stakeholder value realization [35]. Here, values are broadly defined and include any utility the stakeholders may draw as a matter of their engagement with the enterprise [79]. These values include economic (material) values such as financial remunerations earned by employees, dividends drawn by shareholders, services extended to communities, employment opportunities opened for citizens, taxes paid to government, etc. [73,74]. However, they also include human values with moral import such as welfare, privacy, bias avoidance, universal usability, trust, autonomy, creativity, etc. [73,74].

The conscious EA notion aligns with stakeholder theory, which requires enterprises to manage for stakeholders. This notion is consistent with ethical and just organizational leadership principles which could draw mutual trust and benefits to all stakeholders [79]. The sustainability of the enterprise is also dependent on such transparent and fair arrangements of enterprise management. The conscious EA is representative of the essential evolution of the organization towards higher levels of integration and differentiation all at the same time [52]. Through this transformative process, the organization works to "serve both its members and its environment" [52].

The transformation of the enterprise from a mechanistic, to a biological and finally to a socio-technical (socio-cultural) mode entailed changes in its goals. In the mechanistic mode, enterprises are shareholder focused; in the biological mode, they are survival focused; but in the socio-technical mode, they expressly work to serve all their stakeholders [52]. In support of this position, we put forth the following proposition:

\section{Proposition-2. Enterprise architecture is an instrument for promoting stakeholder values.}

\subsection{Social Sustainability as a Criterion in EA Design}

Sustainability is a practical manifestation of systems thinking. More generally, sustainability is striking a balance between the needs of current and of future generations [121]. Sustainability is defined by [122] (11) as "adopting business strategies and activities that meet the needs of the enterprise and its stakeholders today while protecting, sustaining and enhancing the human and natural resources that will be needed in the future".

In the context of EA, the Enterprise Integration school of EA [6] holds that EA aligns strategy with technology [123-125]. Enterprises are moving fast to address not only intragenerational but also inter-generational environmental and social concerns [123]. Yet, economic sustainability still boasts an exalted position [126] relegating social sustainability to a less important status. Scant attention seems to have been paid to human capabilities in EA research and practice [127]. Instead, stakeholders (employees, customers, etc.) appear to be instrumentalized to the extent that they are considered as extensions of technical tools to achieve an economic benefit for the organization [24,25]. 
The HCA is a framework which addresses the social aspect of sustainability as it provides for the evaluation of the impacts of social actions on human capabilities within the context of the structures they are operating in [128].

Several researchers have shown the link between the sustainability approach and the HCA [96,127,129,130]. Burger and Christen [127] argue that the HCA is a natural fit for sustainability as both claim to have normative power and universal validity. The two are also linked to actions intended to improve the quality of life of humans [127]. Corporate social responsibility policies that foster stakeholders' choices further justify the use of the HCA within a sustainability program [131,132].

The ultimate purpose EA should therefore be to preserve and expand human capabilities of current and future generations. In this relation, sustainability is coming up as a progressive research agenda in the EA literature. In parallel, the HCA, with a substantial contribution to sustainability thinking, is being promoted as a valuable theoretical framework in ICT4D and technological design fields. We therefore forward the following proposition:

\section{Proposition-3. Social sustainability is a critical criterion in Enterprise architecture design.}

\subsection{Promoting Human Capabilities Is an Ideal EA Should Promote}

According to systems theory, the evolution of hierarchic systems is from the lower to higher, which implies that the purpose of the supersystem is to serve the purposes of the subsystems [36]. The modern stakeholder is someone who not only works to achieve corporate objectives but their own objectives as well $[46,133]$. Thus, the purpose of the EA is expressed in the multiplicity of stakeholder goals. What is not obvious though is the specific interests of the stakeholders. We argue for the deployment of the HCA in EA in the order to account for and promote stakeholder values and social sustainability [18,91]. The HCA promotes the expansion of human choices [55] thereby removing the unfreedoms which limit humans from living the life they choose [99]. The HCA suggests that a process, system, or technology to be deployed in a social context shall extend the capabilities of humans [49].

The HCA makes a clear distinction between the characteristics of goods and the functionings that a person achieves because of the use of the goods. The focus of the HCA is on the functionings [40]. For instance, if we take a higher education institution, the technical side of EA may dictate the acquisition of hardware and software that meet certain functional and non-functional quality specifications. On the other hand, the HCA informs EA to favour hardware and software that could expand the capabilities of the students, teachers, alumni, etc., by way of expanding their opportunity to flourish. This could be in the form of opportunities of research funds, networking, educational opportunities, research collaboration, etc.

Consistent with stakeholder theory, the HCA recognizes the plurality of the values individuals want to achieve both in quality and quantity [40]. Therefore, an EA that attempts to cater for only a single value of the human stakeholder is ineffectual. Taking the previous example, a higher education institution may, for various reasons, take the wrong assumption that serving the academic needs of the student would suffice. However, academic needs may mean several things to a student or group of students. In addition, the student may have psychological, philosophical, religious, etc., values to promote, which may not be covered by the academic goals. Therefore, the institution needs to look at human flourishing needs instead to stay relevant in the long run.

To demonstrate how stakeholder capability co-creation is possible in EA via the HCA, in Table 3 we present a mapping of stakeholder values to the central human capabilities [19]. We employed the three classes of EA stakeholder roles (producers, facilitators, and users) provided in [116]. Producers are those involved with EA planning and development. Facilitators, on the other hand, are those who plan, manage, maintain, or sponsor EA work. Users are those who provide input, requirements to EA and receive products and services. 
We added a fourth class for the community the enterprise operates in. Note that the classes are not mutually exclusive, and the role of a stakeholder may vary from organization to organization.

Table 3. Mapping the co-creation of EA stakeholder capabilities (adapted from [63]).

\begin{tabular}{|c|c|c|c|c|}
\hline \multirow{2}{*}{ Human Capability } & \multicolumn{4}{|c|}{ Stakeholder Roles } \\
\hline & Producers & Facilitators & Users & Community Members \\
\hline Life & $\begin{array}{l}\text { Ensure work safety and } \\
\text { security; protection } \\
\text { from premature death; } \\
\text { flourishing }\end{array}$ & $\begin{array}{l}\text { Preservation of } \\
\text { investment; } \\
\text { competitiveness; } \\
\text { resilience; flourishing }\end{array}$ & $\begin{array}{c}\text { System } \\
\text { product/service safety; } \\
\text { protection from } \\
\text { premature death; } \\
\text { flourishing }\end{array}$ & $\begin{array}{c}\text { Production safety } \\
\text { (Ecological); quality of } \\
\text { life }\end{array}$ \\
\hline Bodily Health & $\begin{array}{l}\text { Ensure work safety and } \\
\text { security }\end{array}$ & $\begin{array}{l}\text { Preservation of } \\
\text { investment; } \\
\text { sustainability and } \\
\text { resilience; }\end{array}$ & $\begin{array}{l}\text { Ensure bodily health; } \\
\text { provisioning of good } \\
\text { health, nourishment, } \\
\text { and shelter }\end{array}$ & $\begin{array}{c}\text { Ecological } \\
\text { improvement; access to } \\
\text { health }\end{array}$ \\
\hline Bodily Integrity & $\begin{array}{l}\text { Ensure freedom of } \\
\text { movement; security } \\
\text { against any form of } \\
\text { violence including } \\
\text { online harassment; } \\
\text { privacy }\end{array}$ & $\begin{array}{c}\text { Preservation of } \\
\text { investment; privacy }\end{array}$ & $\begin{array}{l}\text { Freedom of movement; } \\
\text { security against any } \\
\text { form of violence } \\
\text { including for example } \\
\text { online bullying }\end{array}$ & $\begin{array}{c}\text { Access to facilities, } \\
\text { services, and resources } \\
\text { (within limit) }\end{array}$ \\
\hline $\begin{array}{c}\text { Sense, imagination, } \\
\text { thought }\end{array}$ & $\begin{array}{l}\text { Ability to express self; } \\
\text { ability to } \\
\text { create/innovate; } \\
\text { education and training } \\
\text { provision }\end{array}$ & $\begin{array}{l}\text { Supporting innovation } \\
\text { and sustainability }\end{array}$ & $\begin{array}{l}\text { Self-actualization; } \\
\text { self-expression } \\
\text { opportunities }\end{array}$ & $\begin{array}{l}\text { Supporting community } \\
\text { capacity building } \\
\text { through training, } \\
\text { education, } \\
\text { collaboration }\end{array}$ \\
\hline Emotions & $\begin{array}{l}\text { Motivation and job } \\
\text { satisfaction }\end{array}$ & $\begin{array}{l}\text { Social investing; } \\
\text { corporate social } \\
\text { responsibility; ensure } \\
\text { justice and security }\end{array}$ & $\begin{array}{l}\text { Safe emotional } \\
\text { engagement with } \\
\text { others; maintenance of } \\
\text { cultural values }\end{array}$ & $\begin{array}{l}\text { Supporting community } \\
\text { development; human } \\
\text { rights and peace }\end{array}$ \\
\hline Practical Reasons & $\begin{array}{l}\text { Input to quality } \\
\text { management system; } \\
\text { stakeholder } \\
\text { engagement; capacity } \\
\text { to exercise practical } \\
\text { reason }\end{array}$ & $\begin{array}{l}\text { Meaningful sponsor } \\
\text { participation }\end{array}$ & $\begin{array}{l}\text { Informed choice; } \\
\text { freedom of conscience }\end{array}$ & $\begin{array}{l}\text { Community planning; } \\
\text { involvement in } \\
\text { decision making; } \\
\text { opportunity expansion }\end{array}$ \\
\hline Affiliation & $\begin{array}{l}\text { Meaningful social } \\
\text { interaction; ensuring } \\
\text { freedom of assembly; } \\
\text { ability to have } \\
\text { uncensored } \\
\text { communication with } \\
\text { others }\end{array}$ & $\begin{array}{c}\text { Joining a community of } \\
\text { sponsors or facilitators; } \\
\text { engagement with other } \\
\text { leaders }\end{array}$ & $\begin{array}{l}\text { Meaningful user } \\
\text { interaction; dignity }\end{array}$ & $\begin{array}{c}\text { Meaningful } \\
\text { community-producer } \\
\text { interaction; } \\
\text { intra-community } \\
\text { interactions }\end{array}$ \\
\hline $\begin{array}{l}\text { Relation to nature } \\
\text { (Other species) }\end{array}$ & $\begin{array}{l}\text { Ability to show } \\
\text { concern for the } \\
\text { ecosystem; Green } \\
\text { information system }\end{array}$ & $\begin{array}{c}\text { Sustainability } \\
\text { investment; Corporate } \\
\text { social responsibility }\end{array}$ & $\begin{array}{l}\text { Benefit from green } \\
\text { products and services }\end{array}$ & Green future; \\
\hline Play & Work-life balance & Supporting innovation & Capacity to play & $\begin{array}{l}\text { Capacity to benefit } \\
\text { from green investments }\end{array}$ \\
\hline $\begin{array}{l}\text { Control over } \\
\text { environment }\end{array}$ & $\begin{array}{l}\text { Being able to work as a } \\
\text { human being; equal } \\
\text { employment } \\
\text { opportunity; }\end{array}$ & $\begin{array}{l}\text { Property right } \\
\text { protections; } \\
\text { transparency }\end{array}$ & $\begin{array}{l}\text { Free participation in the } \\
\text { political and economic } \\
\text { life of the society }\end{array}$ & $\begin{array}{l}\text { Transparent local } \\
\text { democratic } \\
\text { participation; } \\
\text { citizenship }\end{array}$ \\
\hline
\end{tabular}


As noted in Section 2, organizations could play the negative role of alienation, repression, and domination in many societies. This is because there are tensions among the owner, manager, employees, and the wider community as the interests of all these groups often diverge [134]. Table 3 demonstrates HCA's utility as a theoretical counterweight to instrumentality and the associated theories of dehumanization and alienation [135]. This is a worthy agenda to consider in EA theory and practice. We suggest the HCA as a conceptual bond to bring forth stakeholder value promotion and sustainability to EA theory and practice.

Within the wider domain of EA, the HCA may be used in:

1. establishing the information base necessary to perform the mission of the enterprise;

2. setting up the structures requisite to implement the enterprise mission;

3. determining the kinds of principles that place design limit on EA;

4. determining the technologies necessary to perform the mission of the enterprise as well as promote the welfare of humans and their environment;

5. determining the techniques and tools used in EA planning and implementation; and 6. evaluating or comparing EA efforts from human function achievement perspective.

Adopting the HCA as a guiding framework would mean anchoring EA design on the principles of equity, justice, well-being, and human agency. EA Principles that reflect the capability promoting ideals of the HCA would guide the design of technologies and structures. The techniques and tools of EA development would become capability sensitive, inclusive, and participatory. The overall goal should, however, be embedding human capability consciousness in EA [70]. As such, we forward the following proposition:

Proposition-4. Promoting human capabilities is an ideal that EA should promote.

\section{Implications of Stated Propositions}

What follow are the implications that emanate from the propositions presented in Section 4.

\subsection{Generic Implications}

The role the HCA can play in EA can be understood with the use of the cartwheel model of Robeyns [56]. In Figure 2, core characteristics of the HCA lie at the center. At the end of each of the spokes radiating from the center are the modules, which define the contextual purpose and associated instruments and assumptions.

The cartwheel is like a template from which contextual implementations (capability theories) can be instantiated. For example, the HCA as applied in public health EA may take theoretical, ontological, and ethical assumptions different from when it is applied in a corporate EA context. Yet, there are elements which are commonly shared by all implementations of the template. The core (human capabilities) represents those shared elements [56].

The purpose defines the specific utility the HCA is serving in a project. For example, in the context of EA, the HCA could be deployed to develop principles that guide EA projects, or to evaluate impacts of implementations, or to make comparisons among artefacts or implementations, etc.

The purpose then determines the meta-theoretic commitments one may make. Empirical studies, moral argumentations, and qualitative evaluations may demand differing metatheoretic commitments. For instance, Bolat [136] used the HCA within the grounded theory methodology to study mobile technology deployment with relation to innovation practices among business-to-business (B2B) firms.

A wide variety of ontological and explanatory theories are available to account for and explain human nature and choices. As an example [137], studied assistive technologies using the HCA and the biopsychosocial model of disability. On the other hand [138], deployed a HCA within a critical realist philosophy to study mobile phone use among people with 
disabilities [139], showed the possibility of blending critical realism, hermeneutics, and complexity theory to develop a relational ontology of capabilities.

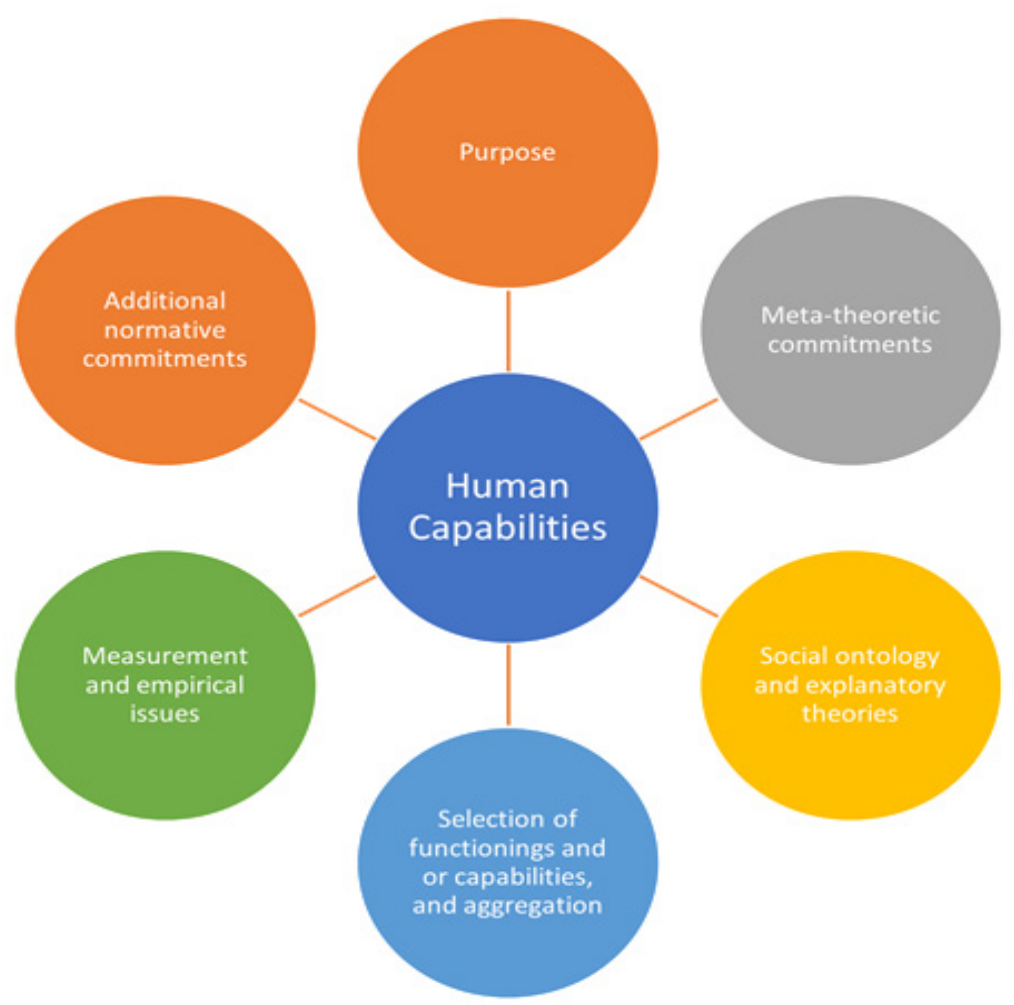

Figure 2. Cartwheel view of the HCA (adopted from [56]).

Then, a selection of functionings and/or capabilities is made considering the task at hand. For example, a list of capabilities based on empirical research could be selected [140]. It is also possible to use, for instance, Nussbaum's central capabilities [141] or other similar lists.

Measurement and empirical issues - methodologies, methods, techniques, tools, and data sets to be used are determined in line with the decisions made thus far. As an example [142], presented two empirical case studies from Brazil and Zambia drawing on the HCA and critical theory [140], discussed instances of both quantitative and qualitative empirical techniques employed along with the HCA.

An optional module in the cartwheel view is the use of additional moral principles to supplement or enrich the HCA. Where needed, the researcher or practitioner can add moral principles not accounted in the foundational capabilities. For example, [143] integrated procedural ethics with HCA and value-sensitive design in a humanitarian cargo drone study.

In conclusion, the HCA provides a range of ontological, epistemological, theoretical, methodological, and ethical choices for its purposeful application in EA research and practice.

\subsection{Implications for Academics}

The strengthening of EA's theoretical foundation is identified as a worthy endeavor since much of the effort so far has been in reinforcing the praxis than building the theoretical basis [4]. In this respect, the introduction of the HCA into EA theory is a novel contribution as far as our reading of the current state of the EA literature is concerned. It could be used to expand on the ecological school of EA with emphasis on the human-centered agenda [4].

This paper invites researchers to forcefully challenge the status quo in the interest of enshrining stakeholder values in EA design. The need for an expansive venture to apprehend stakeholder interests is emphasized. An aspect of EA theory that is drawing attention 
is the drive towards holism and within it the question of putting EA on a sustainability pedestal. This conceptual paper would contribute towards the holistic treatment of EA. It would add to the growing call for assigning a prominent role to the social component of EA $[4,115]$.

The HCA has rarely been applied in the corporate sector as much as in a public policy context. This has perhaps helped to accentuate its normative rationale more than its potential economic benefits to enterprises. In this paper, we attempted to show its potential in EA planning and evaluation, both in the business and public sectors. The paper will hopefully enrich the HCA literature as it explores new territories for the application of the theory.

Although there are efforts to investigate EA through the lens of economic, environmental, and social sustainability, we feel that there is room for improvement by attacking the problems of viability and sustainability from the perspective of the individual (the problem of atomism, in sociological parlance) $[4,13,144]$. The HCA considers the individual as the core element of analysis for social enterprise without the need to relegate social concerns [145].

Furthermore, consequent to the propositions presented in Section 4, the following research strands may need investigation.

- With the introduction of the HCA to EA theory, a new path of comprehensive research integrating normative ethics into EA is opened. As a preface, researchers may investigate the extent to which stakeholder interests drive current EA theory and practice.

- We argued that human capabilities expansion is the true goal of EA. A potential research strand that needs some empirical data is the extent to which EA efforts, by design, contribute to human capabilities expansion.

- Stakeholders pursue different goals that can often be in contradiction. It is therefore imperative to look for mechanisms, techniques, and tools for prioritizing and optimizing these stakeholders and their goals in enterprise architecting [117].

- We see a potential answer in human capabilities consciousness for the question posed by Bernus et al. [13] regarding what they call the meaning of survival in the context of EA. They argue, EA must define the values and principles that govern what and why needs to sustain. An in-depth inquiry into the problem (EA survival mode) and our potential solution domain (human capabilities) is suggested.

\subsection{Implications for Practitioners}

In this paper, we endorse the systems perspectives for understanding and diagnosing EA's positioning in organizations. Across all aspects of the EA, systems thinking should be infused for the successful implementation of EA projects. Particularly focusing on the purpose of a system is essential to understand the structures and interactions of the system [78].

A corollary to this implication is systems thinking shall inform the enterprise's sustainability drive. As Meadows and Wright [36] suggested, the overall purpose of enterprise management should not only be to manage for productivity or stability but also for sustainability and resilience. Though sustainability works at different levels, we presented the HCA as a theoretical framework to anchor sustainability at the level of the individual or of the group.

EA is a balancing act among the interests of competing, cooperating, and co-opting stakeholder interests. Stakeholder theory can be used in identifying stakeholders and choosing which stakeholders and what stakes matter [146]. For example, [87] proposed a theory of stakeholder identification and salience to organizations based on power, legitimacy, and urgency attributes. The role of the HCA would be to reorient the decision-making process to focus on what matters- the achievement of human functions. As [63] indicate, stakeholder capability enhancement can bring about cooperative and competitive advantages to stakeholders through achievement of their functionings. 
Another implication of the propositions is that continuous learning is recommended to make sustainable change possible. Complex systems such as enterprises can only survive if they can cope with the socio-cultural changes in the environment. The transformation towards more differentiation means that EA should align with this paradigmatic shift. Enterprise architects should make agility their guiding principle in order to make continuous learning possible.

To reiterate what we have said in Section 4.4, the HCA could become an integral component of EA planning and evaluation frameworks. From determining missions, visions, and principles to selection of methods and technologies and evaluation of impacts, the HCA could inform EA practice and (re)direct organizational efforts towards realization of the organization's telos-human flourishing.

\section{Conclusions}

The motivation for this research was the felt need for a holistic integration of the technical and non-technical aspects of EA. In this paper, we have tried to show that the HCA can be used as an integrative framework in EA. We showed that human capabilities consciousness in EA is at its early stage though latest research outputs have indicated in the direction of holism. We emphasized the need for integration of different human oriented concepts as they relate to technological change. The culmination of the research were the four propositions made which form a logical chain, one leading to the next. Table 4 summarizes the propositions.

Table 4. Summary of propositions.

\begin{tabular}{|c|c|c|}
\hline ID & Proposition & Explanation \\
\hline Proposition-1 & $\begin{array}{c}\text { Enterprise architecture is socio-technical } \\
\text { architecture. }\end{array}$ & $\begin{array}{l}\text { The technical aspect of EA has been given much more emphasis } \\
\text { than the social. We argue, the human component should come } \\
\text { forward for a better understanding and realization of EA goals. }\end{array}$ \\
\hline Proposition-2 & $\begin{array}{l}\text { Enterprise architecture is an instrument } \\
\text { for promoting stakeholder values. }\end{array}$ & $\begin{array}{l}\text { Stakeholders are usually treated as instruments for enterprise } \\
\text { goals realization. We argue, stakeholders may have } \\
\text { interests/values which they want to promote. EA, as a strategic } \\
\text { tool, should be wielded not to suppress, but to promote, } \\
\text { stakeholder needs. }\end{array}$ \\
\hline Proposition-3 & $\begin{array}{l}\text { Social sustainability is a critical criterion } \\
\text { in enterprise architecture design. }\end{array}$ & $\begin{array}{l}\text { Enterprises have been given an exalted position to economic } \\
\text { sustainability. The recognition that the enterprise needs to } \\
\text { promote stakeholder values leads to the conclusion that social } \\
\text { and environmental sustainability are equally important. The } \\
\text { enterprise will be strategically better off by recognizing and } \\
\text { working towards social and environmental sustainability. }\end{array}$ \\
\hline Proposition-4 & $\begin{array}{l}\text { Promoting human capabilities is an ideal } \\
\text { EA should promote. }\end{array}$ & $\begin{array}{l}\text { In conclusion, EA should serve the purpose of promoting } \\
\text { human capabilities. The very purpose of enterprises is to serve } \\
\text { the higher goal of human flourishing. }\end{array}$ \\
\hline
\end{tabular}

The philosophical position that any human made system's purpose is to further the interest of humans is underscored. To this effect, EA should be understood as sociotechnical architecture the purpose of which is to expand the choices of enterprise human stakeholders. We argued that, from a human-centric perspective, choice expansion is the fundamental utility provided by the enterprise.

From stakeholder theory, we gather that the enterprise is where a multitude of interests meet, negotiate, and optimize their goals. We agree with Nightingale and Rhodes [147] (4) when they say, "[e]nterprises exist to deliver value to stakeholders."

Human consciousness is in the ascendence in all human endeavors. EA should embrace this trend to stay relevant. This study, by providing a better understanding of human-capabilities in the context of EA, may help promote human-capabilities conscious practices. We argued that the conscious purpose-capability expansion—should define en- 
terprise structures. We assert that capability expansion is a worthy endeavor the enterprise should work to achieve through EA.

Author Contributions: Both authors contributed to the research. E.A.K. contributed to the conceptualization, methodology, formal analysis, investigation, and writing. J.C.M. contributed towards the resources, supervision, validation, and revision of the paper. All authors have read and agreed to the published version of the manuscript.

Funding: This research received no external funding.

Acknowledgments: The authors are extremely grateful to the anonymous reviewers for their valuable comments and suggestions.

Conflicts of Interest: The authors declare no conflict of interest.

\section{References}

1. Jonkers, H.; Lankhorst, M.M.; ter Doest, H.W.L.; Arbab, F.; Bosma, H.; Wieringa, R.J. Enterprise Architecture: Management Tool and Blueprint for the Organisation. Inf. Syst. Front. 2006, 8, 63-66. [CrossRef]

2. Gorkhali, A.; Xu, L. Da Enterprise Architecture: A Literature Review. J. Ind. Integr. Manag. 2017, 02, 1750009. [CrossRef]

3. Júnior, S.H.d.L.; Silva, F.Í.C.; Albuquerque, G.S.G.; de Medeiros, F.P.A.; Lira, H.B. Enterprise Architecture in Healthcare Systems: A Systematic Literature Review. arXiv 2020, arXiv:2007.06767. [CrossRef]

4. Lapalme, J.; Gerber, A.; Van Der Merwe, A.; Zachman, J.; de Vries, M.; Hinkelmann, K. Exploring the Future of Enterprise Architecture: A Zachman Perspective. Comput. Ind. 2015. [CrossRef]

5. Kotusev, S. The History of Enterprise Architecture: An Evidence-Based Review. J. Enterp. Archit. 2016, $12,29-37$.

6. Lapalme, J. Three Schools of Thought on Enterprise Architecture. IT Prof. 2012, 14, 37-43. [CrossRef]

7. Korhonen, J.J.; Poutanen, J. Tripartite Approach to Enterprise Architecture. J. Enterp. Archit. 2013, 9, 28-38. [CrossRef]

8. Spewak, S.H.; Hill, S.C. Enterprise Architecture Planning: Developing a Blueprint for Data, Applications, and Technology; 1993; ISBN 0471599859. Available online: dl.acm.org (accessed on 2 July 2021).

9. Handley, H. A Socio-Technical Architecture. Top. Saf. Risk Reliab. Qual. 2019, 35, 27-38. [CrossRef]

10. Simon, D.; Fischbach, K.; Schoder, D. An Exploration of Enterprise Architecture Research. Commun. Assoc. Inf. Syst. 2013, 32, 1-71. [CrossRef]

11. Panetto, H.; Zdravkovic, M.; Jardim-Goncalves, R.; Romero, D.; Cecil, J.; Mezgár, I. New Perspectives for the Future Interoperable Enterprise Systems. Comput. Ind. 2016, 79, 47-63. [CrossRef]

12. Romero, D.; Vernadat, F. Enterprise Information Systems State of the Art: Past, Present and Future Trends. Comput. Ind. 2016, 79, 3-13. [CrossRef]

13. Bernus, P.; Goranson, T.; Gøtze, J.; Jensen-Waud, A.; Kandjani, H.; Molina, A.; Noran, O.; Rabelo, R.J.; Romero, D.; Saha, P.; et al. Enterprise Engineering and Management at the Crossroads. Comput. Ind. 2016, 79, 87-102. [CrossRef]

14. Kotusev, S.; Kurnia, S. The Theoretical Basis of Enterprise Architecture: A Critical Review and Taxonomy of Relevant Theories. J. Inf. Technol. 2020. [CrossRef]

15. Weiss, S.; Aier, S.; Winter, R. Towards a Reconstruction of Theoretical Foundations of Enterprise Architecture Management. In Information Systems: Crossroads for Organization, Management, Accounting and Engineering; Physica-Verlag HD: Heidelberg, Germany, 2012; pp. 461-468; ISBN 9783790827897.

16. InformationWeek Gartner Advises Enterprises To Adopt An “Emergent Architecture". Available online: https://www. informationweek.com/software/information-management/gartner-advises-enterprises-to-adopt-an-emergent-architecture/ d/d-id/1082301? (accessed on 28 June 2021).

17. MacInnis, D.J. A Framework for Conceptual Contributions in Marketing. J. Mark. 2011, 75, 136-154. [CrossRef]

18. Sen, A.K. Development as Freedom; Oxford Paperbacks: Oxford, UK, 1999; ISBN 978-0-19-289330-7.

19. Nussbaum, M.C. Creating Capabilities: The Human Development Approach; Harvard University Press: London, UK, 2011; ISBN 978-0-674-05054-9.

20. Jaakkola, E. Designing Conceptual Articles: Four Approaches. AMS Rev. 2020, 10, 18-26. [CrossRef]

21. Mora, M.; Gelman, O.; Paradice, D.; Cervantes, F. The Case for Conceptual Research in Information Systems. In Proceedings of the International Conference on Information Resources Management (CONF-IRM), Niagra Falls, ON, Canada, 18-20 May 2008.

22. Gilson, L.L.; Goldberg, C.B. Editors' Comment: So, What Is a Conceptual Paper? Gr. Organ. Manag. 2015, 40, 127-130. [CrossRef]

23. McGregor, S.L.T. Understanding and Evaluating Research: A Critical Guide; SAGE Publications, Inc.: Thousand Oaks, CA, USA, 2018; ISBN 9781506350950.

24. Mingers, J.; Walsham, G. Toward Ethical Information Systems: The Contribution of Discourse Ethics. MIS Q. 2010, $34,833-854$. [CrossRef]

25. Hoogervorst, J. The Imperative for Employee-Centric Organizing and Its Significance for Enterprise Engineering. Organ. Des. Enterp. Eng. 2017, 1, 43-58. [CrossRef] 
26. Mackey, J.; Sisodia, R. Conscious Capitalism: Liberating the Heroic Spirit of Business; Harvard Business Review Press: Boston, MA, USA, 2014; ISBN 1625271751.

27. Nussbaum, M.C. Objectification. Philos. Public Aff. 1995, 24, 249-291. [CrossRef]

28. Marx, K.; Engels, F. The Economic and Philosophic Manuscripts of 1844 and the Communist Manifesto; Prometheus Books: Amherst, NY, USA, 2009; ISBN 978-0-87975-446-4.

29. Aristotle; Reeve, C.D.C. Metaphysics; Hackett Publishing Company, Inc.: Indianapolis, IN, USA, 2016; ISBN 978-162466439-7.

30. Aristotle; Reeve, C.D.C. Physics (The New Hackett Aristotle); Hackett Publishing Company, Inc.: Indianapolis, IN, USA, 2018; ISBN 978-162466691-9.

31. Falcon, A. Aristotle on Causality. In The Stanford Encyclopedia of Philosophy; Zalta, E.N., Ed.; Metaphysics Research Lab, Stanford University: Stanford, CA, USA, 2019.

32. Hoogervorst, J.A.P. Enterprise Governance and Enterprise Engineering; Springer Science \& Business Media: Berlin, Germany, 2009; ISBN 978-3-540-92670-2.

33. Giachetti, R.E. Design of Enterprise Systems; CRC Press: Boca Raton, FL, USA, 2010; ISBN 9781439882894.

34. Hatch, M.J. Organizations: A Very Short Introduction; Oxford University Press: Oxford, UK, 2011.

35. Dekkers, R. Applied Systems Theory, 2nd ed.; Springer International Publishing: Cham, Switzerland, $2017 ;$ ISBN 9783319575261.

36. Meadows, D.H.; Wright, D. Thinking in Systems: A Primer; Chelsea Green Publishing: White River Junction, VT, USA, 2015; ISBN 9781603580557.

37. Jasanoff, S. The Ethics of Invention: Technology and the Human Future; W. W. Norton \& Company, Inc.: New York, NY, USA, 2016; ISBN 9780393253856.

38. Pastor-Escuredo, D. Ethics in the Digital Era. Available online: http:/ /arxiv.org/abs/2003.06530v3 (accessed on 28 June 2021).

39. Sullivan, L.S.; Reiner, P.B. Ethics in the Digital Era: Nothing New? IT Prof. 2020, 22, 39-42. [CrossRef]

40. Enderle, G. The Capability Approach as Guidance for Corporate Ethics. In Handbook of the Philosophical Foundations of Business Ethics; Luetge, C., Ed.; Springer Dordrecht: Dordrecht, The Netherlands, 2013; pp. 675-691; ISBN 978-94-007-1494-6.

41. Stiglitz, J.; Sen, A.; Fitoussi, J. Report by the Commission on the Measurement of Economic Performance and Social Progress. 2009. Available online: citeseerx.ist.psu.edu/viewdoc/download?doi=10.1.1.215.58\&rep=rep1\&type=pdf (accessed on 2 July 2021).

42. Solomon, R.C. Aristotle, Ethics and Business Organizations. Organ. Stud. 2004, 25, 1021-1043. [CrossRef]

43. Daft, R.L. Organizational Theory and Design, 10th ed.; Thomson South-Western: Mason, OH, USA, 2007 ; ISBN 0324405421.

44. Mentz, J.C.; Kotzé, P.; van der Merwe, A. Propositions that Describe the Intended Meaning of Enterprise Architecture. In Proceedings of the Southern African Institute for Computer Scientist and Information Technologists Annual Conference 2014SAICSIT '14; ACM Press: New York, NY, USA, 2014; pp. 304-313.

45. Avram, A. Reactions to Gartner's Suggestion to Use an "Emergent Architecture". Available online: https://www.infoq.com/ news/2009/08/Emergent-Architecture/ (accessed on 28 June 2021).

46. Morgan, J. The Future of Work-Attract New Talent, Build Better Leaders, and Create a Competitive Organization; Wiley: Hoboken, NJ, USA, 2014; ISBN 978-1-118-87729-6.

47. Korhonen, J.J.; Lapalme, J.; McDavid, D.; Gill, A.Q. Adaptive Enterprise Architecture for the Future: Towards a Reconceptualization of EA. In Proceedings of the 2016 IEEE 18th Conference on Business Informatics (CBI), Paris, France, 24-26 August 2016; pp. 272-281.

48. Harmon, K. The "Systems" Nature of Enterprise Architecture. In Proceedings of the 2005 IEEE International Conference on Systems, Man and Cybernetics, NW Washington, DC, USA, 15-17 August 2005; pp. 78-85.

49. Oosterlaken, I. The capability approach, technology and design: Taking stock and looking ahead. In The Capability Approach, Technology and Design; Oosterlaken, I., van den Hoven, J., Eds.; Springer: Dordrecht, The Netherlands, 2012; Volume 5, pp. 3-26; ISBN 978-94-007-3878-2.

50. Oosterlaken, I. Design for Development: A Capability Approach. Des. Issues 2009, 25, 91-102. [CrossRef]

51. Drews, P.; Schirmer, I. From Enterprise Architecture to Business Ecosystem Architecture: Stages and Challenges for Extending Architectures beyond Organizational Boundaries. In Proceedings of the 2014 IEEE 18th International Enterprise Distributed Object Computing Conference Workshops and Demonstrations, Ulm, Germany, 1-2 September 2014; pp. 13-22.

52. Gharajedaghi, J. Systems Thinking: Managing Chaos and Complexity, 3rd ed.; Elsevier Inc.: Amsterdam, The Netherlands, 2011.

53. Freeman, R.E.; Wicks, A.C.; Parmar, B. Stakeholder Theory and "The Corporate Objective Revisited". Organ. Sci. 2004, 15, 364-369. [CrossRef]

54. Laplume, A.O.; Sonpar, K.; Litz, R.A. Stakeholder theory: Reviewing a theory that moves us. J. Manag. 2008, 34, 1152-1189. [CrossRef]

55. Robeyns, I. Capability Ethics. In The Blackwell Guide to Ethical Theory; Blackwell Publishing Ltd: Oxford, UK, 2017 ; pp. 412-432.

56. Robeyns, I. Capabilitarianism. J. Hum. Dev. Capab. 2016, 17, 397-414. [CrossRef]

57. Bonnafous-Boucher, M.; Dahl Rendtorff, J. Stakeholder Theory: A Model for Strategic Management; Springer International Publishing: Cham, Switzerland, 2016; ISBN 978-3-319-44356-0.

58. Cantón, C.G. Empowering People in the Business Frontline: The Ruggie's Framework and the Capability Approach. Manag. Rev. 2012, 23, 191-216. [CrossRef] 
59. Kloeckner, S.; Birkmeier, D. Something Is Missing: Enterprise Architecture from a Systems Theory Perspective. In Service-Oriented Computing: Icsoc/Service Wave 2009 Workshops; Dan, A., Gittler, F., Toumani, F., Eds.; Springer: Berlin/Heidelberg, Germany, 2010; Volume 6275, pp. 22-34; ISBN 978-3-642-16132-2.

60. Savage, G.; Franz, A.; Holacratic, A.A.; Architecture, S.S. A Holacratic Socio-Technical System Architecture. 2016 IEEE Int. Symp. Syst. Eng. 2016, 1-6. [CrossRef]

61. Davis, J.B. The Capabilities Conception of the Individual. Rev. Soc. Econ. 2009, 67, 413-429. [CrossRef]

62. Mizohata, S. Amartya Sen's Capability Approach, Democratic Governance and Japan's Fukushima Disaster. Available online: https: / / apjjf.org/2011/9/39/Sachie-MIZOHATA/3648/article.html (accessed on 2 July 2021).

63. Westermann-Behaylo, M.K.; Van Buren, H.J.; Berman, S.L. Stakeholder Capability Enhancement as a Path to Promote Human Dignity and Cooperative Advantage. Bus. Ethics Q. 2016, 26, 529-555. [CrossRef]

64. Von Bertalanffy, L. General System Theory: Foundations, Development, Applications; Braziller: New York, NY, USA, 2009; ISBN $0807604534,9780807604533$.

65. Hoyland, C.A. An Analysis of Enterprise Architectures Using General Systems Theory. In Proceedings of the 2011 IEEE International Conference on Systems, Man, and Cybernetics, Anchorage, AK, USA, 9-12 October 2011; pp. 340-344.

66. Freeman, R.E. Strategic Management: A Stakeholder Approach; Pitman Series in Business and Public Policy; Cambridge University Press: Cambridge, UK, 2010; ISBN 9780521151740.

67. Fox, W.M. Sociotechnical System Principles and Guidelines: Past and Present. J. Appl. Behav. Sci. 1995, 31, 91-105. [CrossRef]

68. Clegg, C.W. Sociotechnical Principles for System Design. Appl. Ergon. 2000, 31, 463-477. [CrossRef]

69. Stillman, L.; Denison, T. The Capability Approach Community Informatics. Inf. Soc. 2014. [CrossRef]

70. Oosterlaken, I. Human Capabilities in Design for Values. In Handbook of Ethics, Values, and Technological Design; van den Hoven, J., Vermaas, P.E., van de Poel, I., Eds.; Springer Netherlands: Dordrecht, The Netherlands, 2014; pp. 1-26; ISBN 978-94-007-6994-6.

71. Apsan Frediani, A.; Boni, A.; Gasper, D. Approaching Development Projects from a Human Development and Capability Perspective. J. Hum. Dev. Capab. 2014, 15, 1-12. [CrossRef]

72. Hasan, H.; Kazlauskas, A. Making Sense of IS with the Cynefin Framework. In Proceedings of the PACIS 2009, Hyderabad, India, 10-12 July 2009.

73. Friedman, B.; Kahn, P.H., Jr.; Borning, A. Value Sensitive Design and Information Systems. Hum. Comput. Interact. Manag. Inf. Syst. Found. 2006, 1-27. [CrossRef]

74. Friedman, B.; Kahn, P.H. Human values, ethics, and design. In The Human-Computer Interaction Handbook; Sears, A., Jacko, J.A., Eds.; Taylor \& Francis Group: New York, NY, USA, 2008; pp. 1241-1266; ISBN 978-0-8058-5870-9.

75. Morgan, G. Images of Organization; Updated; SAGE Publications: Thousand Oaks, CA, USA, 2006 ; ISBN 9781412939799.

76. Weinberg, G.M. An Introduction to General Systems Thinking; Dorset House: New York, NY, USA, $2001 ;$ ISBN 9780932633491.

77. Anderson, V.; Johnson, L. Systems Thinking Basics: From Concepts to Causal Loops; Pegasus Workbook Series; Pegasus Communications: Cambridge, UK, 1997; ISBN 9781883823122.

78. Coldicott, T.; Kinsella, K.; Campbell, D. Systemic Work with Organizations: A New Model for Managers and Change Agents; Systemic Thinking and Practice Series; Brunner/Mazel: New York NY, USA, 1995.

79. Harrison, J.S. Stakeholder Theory. In Encyclopedia of Management Theory; SAGE Publications Ltd: Thousand Oaks, CA, USA, 2013; pp. 764-777.

80. Miles, J.A. Management and Organization Theory: A Jossey-Bass Reader; Jossey-Bass: San Francisco, CA, USA, 2012; ISBN 9781118008959.

81. Cunliffe, A.L. Organization Theory; SAGE Course Companions Series; SAGE Publications: London, UK, 2008 ; ISBN 9781849204927.

82. Jones, G.R. Organizational Theory, Design, and Change; Pearson: Boston, MA, USA, 2013; ISBN 9780273765608.

83. Hatch, M.J. Organization Theory: Modern, Symbolic, and Postmodern Perspectives; Oxford University Press: Oxford, UK, 2018; ISBN 9780198723981.

84. Phillips, R.; Freeman, R.E.; Wicks, A.C. What Stakeholder Theory Is Not. Bus. Ethics Q. 2003, 13, 479-502. [CrossRef]

85. Op 't Land, M.; Proper, E.; Waage, M.; Cloo, J.; Steghuis, C. Enterprise Architecture: Creating Value by Informed Governance; Springer: Berlin/Heidelberg, Germany, 2009; ISBN 354085231X.

86. Jamali, D. A Stakeholder Approach to Corporate Social Responsibility: A Fresh Perspective into Theory and Practice. J. Bus. Ethics 2008, 82, 213-231. [CrossRef]

87. Mitchell, R.K.; Agle, B.R.; Wood, D.J. Toward a Theory of Stakeholder Identification and Salience: Defining the Principle of Who and What Really Counts. Acad. Manag. Rev. 1997, 22, 853. [CrossRef]

88. Hillman, A.J.; Keim, G.D. Shareholder Value, Stakeholder Management, and Social Issues: What's the Bottom Line? Strateg. Manag. J. 2001, 22, 125-139. [CrossRef]

89. Gasper, D. What Is the Capability Approach? Its Core, Rationale, Partners and Dangers. J. Socio. Econ. 2007, 36, 335-359. [CrossRef]

90. Wells, T.R. Sen's Capability Approach. In Internet Encyclopedia of Philosophy; Feiser, J., Dowden, B., Eds.; 2012; Available online: philpapers.org (accessed on 2 July 2021).

91. Gasper, D. Sen's Capability Approach and Nussbaum's Capabilities Ethic. J. Int. Dev. 1997, 9, 281-302. [CrossRef]

92. Clark, D.A. The Capability Approach: Its Development, Critiques and Recent Advances. Econ. Ser. Work. Pap. 2005, 18. [CrossRef]

93. Robeyns, I. The Capability Approach: A Theoretical Survey. J. Hum. Dev. 2005, 6, 93-117. [CrossRef] 
94. Alkire, S.; Deneulin, S. The Human Development and Capability Approach. In An Introduction to the Human Development and Capability Approach Freedom and Agency; Deneulin, S., Shahani, L., Eds.; IDRC: Ottawa, ON, Canada, 2009.

95. Kleine, D. ICT4what?-Using the Choice Framework to Operationalise the Capability Approach to Development. J. Int. Dev. 2010, 22, 674-692. [CrossRef]

96. Rauschmayer, F.; Leßmann, O. The Capability Approach and Sustainability. J. Hum. Dev. Capab. 2013, 14, 37-41. [CrossRef]

97. Schultz, E.; Christen, M.; Voget-Kleschin, L.; Burger, P. A Sustainability-Fitting Interpretation of the Capability Approach: Integrating the Natural Dimension by Employing Feedback Loops. J. Hum. Dev. Capab. 2013, 14, 115-133. [CrossRef]

98. Watene, K. Nussbaum's Capability Approach and Future Generations. J. Hum. Dev. Capab. 2013, 14, 21-39. [CrossRef]

99. Zheng, Y.; Stahl, B.C. Technology, Capabilities and Critical Perspectives: What Can Critical Theory Contribute to Sen's Capability Approach? Ethics Inf. Technol. 2011, 13, 69-80. [CrossRef]

100. Michael Olatokun, W. Analysing Socio-Demographic Differences in Access and Use of ICTs in Nigeria Using the Capability Approach. Issues Inf. Sci. Inf. Technol. 2009, 6, 479-496. [CrossRef]

101. Dasuki, S.I.; Abbott, P.; Azerikatoa, D. ICT and Empowerment to Participate. Inf. Dev. 2014, 30, 321-331. [CrossRef]

102. Tshivhase, M.; Turpin, M.; Matthee, M. The Use of Sen's Capability Approach in ICT4D: An Exploratory Review. In Proceedings of the International Conference on Information Resources Management (CONF-IRM), Cape Town, South Africa, 18-20 May 2016.

103. Brödner, P. Reflective Design of Technology for Human Needs. AI Soc. 2013, 28, 27-37. [CrossRef]

104. Bertland, A. Virtue Ethics in Business and the Capabilities Approach. J. Bus. Ethics 2009, 84, 25-32. [CrossRef]

105. Bolman, L.G.; Deal, T.E. Reframing Organizations: Artistry, Choice, and Leadership, 6th ed.; Jossey-Bass: Hoboken, NJ, USA, 2017; ISBN 9781119281818.

106. Brey, P.; Søraker, J.H. Philosophy of Computing and Information Technology. In Philosophy of Technology and Engineering Sciences; Meijers, A., Ed.; Elsevier: Amsterdam, The Netherlands, 2009; Volume 9, pp. 1341-1407; ISBN 9780444516671.

107. Ropohl, G. Philosophy of Socio-Technical Systems. Techné Res. Philos. Technol. 1999, 4, 186-194. [CrossRef]

108. Haines, S.G.; Aller-Stead, G.; McKinlay, J. Enterprise-Wide Change: Superior Results through Systems Thinking; Practicing Organization Development; John Wiley \& Sons: San Francisco, CA, USA, 2005; ISBN 0787976644.

109. Waterson, P.; Eason, K. Revisiting the Sociotechnical Principles for System Design (Clegg, 2000). Adv. Intell. Syst. Comput. 2019, 824, 366-374. [CrossRef]

110. IEEE. IEEE Recommended Practice for Architectural Description for Software-Intensive Systems. IEEE Std 1471-2000 2000, 1-30. [CrossRef]

111. Aier, S. The Role of Organizational Culture for Grounding, Management, Guidance and Effectiveness of Enterprise Architecture Principles. Inf. Syst. E-Bus. Manag. 2014, 12, 43-70. [CrossRef]

112. Proper, E.; Greefhorst, D. The Roles of Principles in Enterprise Architecture. Lect. Notes Bus. Inf. Process. 2010, 70 LNBIP, 57-70. [CrossRef]

113. Syynimaa, N. Taxonomy of Purpose of Enterprise Architecture. In Proceedings of the Twelfth International Conference on Informatics and Semiotics in Organisations, Reading, UK, 19-21 July 2010; pp. 322-328.

114. Zachman, J.A. Enterprise Architecture: The Issue of the Century (Unedited Version 1996). Database Program. Des. 1997, 10, 44-53.

115. Nuryatno, E.; Dobson, P. Examining the Social Aspects of Enterprise Architecture Implementation: A Morphogenetic Approach. In Proceedings of the Australasian Conference on Information Systems, Adelaide, Australia, 30 November-4 December 2015; pp. 1-9.

116. Niemi, E. Enterprise Architecture Stakeholders-a Holistic View. In Proceedings of the AMCIS 2007, Keystone, CO, USA, 9-12 August 2007.

117. van der Raadt, B.; Schouten, S.; van Vliet, H. Stakeholder Perception of Enterprise Architecture. In Software Architecture; Springer: Berlin/Heidelberg, Germany, 2008; pp. 19-34.

118. Lankhorst, M.M. Introduction to Enterprise Architecture. In Enterprise Architecture at Work; The Enterprise Engineering Series; Springer Berlin Heidelberg: Berlin/Heidelberg, Germany, 2017; pp. 1-10; ISBN 978-3-662-53932-3.

119. ISO/IEC/IEEE Systems and Software Engineering-Architecture Description. In ISO/IEC/IEEE 420102011(E) (Revision ISO/IEC 420102007 IEEE Std 1471-2000). Available online: https:/ / www.iso.org/standard/50508.html (accessed on 2 July 2021).

120. Zexian, Y. A New Approach to Studying Complex Systems. Syst. Res. Behav. Sci. 2007, 24, 403-416. [CrossRef]

121. Dyllick, T.; Hockerts, K. Beyond the Business Case for Corporate Sustainability. Bus. Strateg. Environ. 2002, 11, 130-141. [CrossRef]

122. International Institute for Sustainable Developement (IISD); Deloitte \& Touche; Business Council for Sustainable Development. Business Strategy for Sustainable Development: Leadership and Accountability for the '90s; International Institute for Sustainable Development: Winnipeg, MB, Canada, 1992; ISBN 978-1895536003.

123. Sutherland, D.; Hovorka, D. Enterprise Architecture as a Contributor to Sustainability Objectives. In Proceedings of the European Conference on Information Systems (ECIS), Tel Aviv, Israel, 9-11 June 2014.

124. Zachman, J.A. The Framework for Enterprise Architecture: Background, Description and Utility. Available online: https: / / www.zachman.com/resources / ea-articles-reference/327-the-framework-for-enterprise-architecture-backgrounddescription-and-utility-by-john-a-zachman (accessed on 13 February 2021).

125. Pankowska, M. Building Sustainable Information Systems; Linger, H., Fisher, J., Barnden, A., Barry, C., Lang, M., Schneider, C., Eds.; Springer US: Boston, MA, USA, 2013; ISBN 978-1-4614-7539-2. 
126. Visser, W. Corporate Sustainability and the Individual: A Literature Review. Cambridge Program. Sustain. Leadersh. Pap. Ser. 2007, 1, 1-15.

127. Burger, P.; Christen, M. Towards a Capability Approach of Sustainability. J. Clean. Prod. 2011, 19, 787-795. [CrossRef]

128. Demals, T.; Hyard, A. Is Amartya Sen's Sustainable Freedom a Broader Vision of Sustainability? Ecol. Econ. 2014, 102, 33-38. [CrossRef]

129. Martins, N.O. The Place of the Capability Approach within Sustainability Economics. Ecol. Econ. 2013, 95, 226-230. [CrossRef]

130. Ballet, J.; Bazin, D.; Dubois, J.-L.; Mahieu, F.-R. A Note on Sustainability Economics and the Capability Approach. Ecol. Econ. 2011, 70, 1831-1834. [CrossRef]

131. Amini, M.; Bienstock, C.C. Corporate Sustainability: An Integrative Definition and Framework to Evaluate Corporate Practice and Guide Academic Research. J. Clean. Prod. 2014, 76, 12-19. [CrossRef]

132. Blackburn, W.R. The Sustainability Handbook: The Complete Management Guide to Achieving...; Routledge Taylor \& Francis Group: London, UK; New York, NY, USA, 2015; ISBN 1844074951.

133. FirstPost Gartner Identifies New Approach for Enterprise Architecture. Available online: https:/ /www.firstpost.com/business/ market-roundup-sensex-reclaims-51000-mark-nifty-above-15000-level-banks-metals-lead-charge-9372331.html (accessed on 3 March 2021).

134. Farazmand, A. Introduction: The Multifaceted Nature of Modern Organizations. In Modern Organizations: Theory and Practice; Farazmand, A., Ed.; Praeger Publishers: Westport, CT, USA, 2002; ISBN 978-0275961404.

135. Chooback, N. Marx's Theory of Alienation and the Capability Approach: A Comparative Study. Available online: https: //www.academia.edu/1159058/Marxs_Theory_of_Alienation_and_the_Capability_Approach (accessed on 2 July 2021).

136. Bolat, E. Mobile Tech: Superfood or Super Fad of Creative Business? J. Bus. Bus. Mark. 2019, 26, 295-318. [CrossRef]

137. Kenigsberg, P.; Aquino, J.; Bérard, A.; Brémond, F.; Charras, K.; Dening, T.; Droës, R.-M.; Gzil, F.; Hicks, B.; Innes, A.; et al. Assistive Technologies to Address Capabilities of People with Dementia: From Research to Practice. Dementia 2019, 18, 1568-1595. [CrossRef] [PubMed]

138. Iliya, A.A.; Ononiwu, C. Mechanisms for Mobile Phone Use in Empowerment: A Critical Realist Study of People with Disabilities in Nigeria. Electron. J. Inf. Syst. Dev. Ctries. 2021, 87. [CrossRef]

139. Owens, J.; Entwistle, V.A.; Craven, L.K.; Conradie, I. Understanding and Investigating Relationality in the Capability Approach. J. Theory Soc. Behav. 2021, 1-19. [CrossRef]

140. Robeyns, I. The Capability Approach in Practice. J. Polit. Philos. 2006, 14, 351-376. [CrossRef]

141. Harris, C.E. Engineering Responsibility for Human Well-Being. Philos. Eng. Technol. 2015, 22, 91-107. [CrossRef]

142. Poveda, S.; Roberts, T. Critical Agency and Development: Applying Freire and Sen to ICT4D in Zambia and Brazil. Inf. Technol. Dev. 2018, 24, 119-137. [CrossRef]

143. Cenci, A.; Cawthorne, D. Refining Value Sensitive Design: A (Capability-Based) Procedural Ethics Approach to Technological Design for Well-Being. Sci. Eng. Ethics. 2020, 26, 2629-2662. [CrossRef]

144. Epstein, B. Social Ontology. In Stanford Encyclopedia of Philosophy (Summer 2018 Edition); Zalta, E.N., Ed.; Metaphysics Research Lab, Stanford University: Stanford, CA, USA, 2018.

145. Robeyns, I.; Byskov, M.F. The Capability Approach. In Stanford Encyclopedia of Philosophy; Zalta, E.N., Ed.; Metaphysics Research Lab, Stanford University: Stanford, CA, USA, 2020.

146. Donaldson, T.; Preston, L.E. The Stakeholder Theory of the Corporation: Concepts, Evidence, and Implications. Acad. Manag. Rev. 1995, 20, 65. [CrossRef]

147. Nightingale, D.J.; Rhodes, D.H. Architecting the Future Enterprise; The MIT Press: Cambridge, MA, USA, $2015 ;$ ISBN 9780262028820. 